\title{
Bacteriostatic Effects of Hyaluronan-Based Bioresorbable Membrane
}

\author{
Keiichi Uchida, Kohei Otake, Mikihiro Inoue, Yuhki Koike, Kohei Matsushita, \\ Koji Tanaka, Yasuhiro Inoue, Yasuhiko Mohri, Masato Kusunoki \\ Department of Gastrointestinal and Pediatric Surgery, Graduate School of Medicine, \\ Mie University, Tsu, Mie, Japan \\ E-mail:ucchie@clin.medic.mie-u.ac.jp \\ Received June 14, 2011; revised September 16, 2011; accepted October 31, 2011
}

\begin{abstract}
Purpose: The purpose of this study is to determine the presence of bacteriostatic effects of hyaluronan-based bioresorbable membrane (HA/CMC) on selected major bacterial strains in digestive organs. Methods: We firstly evaluated the growth inhibition effect of $\mathrm{HA} / \mathrm{CMC}$ for $E$. coli and $S$. aureus by determining the optical density $(\mathrm{OD})_{650}$ in the incubation medium. At second, to determine the viable counts of bacteria, total adenosine triphosphate (ATP) were measured with five groups; several concentrations of HA/CMC and control. Results: OD curve gradually elevated and reached to plateau at 4 hours in E. coli. and 6 hours in S. aureus. After reaching plateau, the growth inhibition of both strains was statistically significantly correlated to the concentrations of $\mathrm{HA} / \mathrm{CMC}$. The ATP productions had statistically significant differences at 6 hours after incubation and inhibited in dose-dependence of a well-dissolved HA/CMC. Conclusion: HA/CMC may have dose-dependently bacteriostatic effects on $S$. aureus and $E$. coli.
\end{abstract}

Keywords: HA/CMC, Bacteriostatic, Hyaluronan, Adhesion, Surgery

\section{Introduction}

Clinical effectiveness and safety of hyaluronan-based bioresorbable membrane $(\mathrm{HA} / \mathrm{CMC})$ on preventing intraperitoneal adhesions has been widely accepted in abdominal and pelvic surgical use [1-4]. Recently, a few cases with postoperative intraperitoneal infection and inflammation after $\mathrm{HA} / \mathrm{CMC}$ placement have been reported $[5,6]$. Though the relationship between HA/CMC and such morbidities was not clear, several clinical and animal studies demonstrated that $\mathrm{HA} / \mathrm{CMC}$ neither resulted in the propagation of infection, nor affected abscess formation, intraperitoneal septic condition and systemic inflammatory response adversely [7-10].

A previous study at our institute [11] demonstrated that HA/CMC did not aggravate an inflammatory cytokine response or produce extensive intra-abdominal adhesions, even in patients with intraperitoneal septic complications and rat models with bacterial peritonitis induced by cecal ligation and puncture. In experimental basic study, K. Otake et al. [12] revealed HA/CMC itself does not affect the functions of isolated human Polymorphonuclear neutrophils in in vitro experimental mo- dels of inflammation and endotoxin-stimulation. Although our results showed that $\mathrm{HA} / \mathrm{CMC}$ can be safely used even in contaminated conditions, further basal experiments about $\mathrm{HA} / \mathrm{CMC}$ against infectious pathogens are needed.

$\mathrm{HA} / \mathrm{CMC}$ is a bioresorbable membrane made of sodium hyaluronate (Hyaruronic acid, HA) and another polyanionic poly saccharide, carboxymethylcellulose (CMC). These components are chemically modified to reduce water solubility and provide longer in vivo residence time than the native polymers. Preclinical evaluation demonstrated that HA/CMC is nontoxic, nonmutagenic, nonimmunogenic, nonirritating and nonpyrogenic [13]. $\mathrm{HA}$ is a connective tissue glycosaminoglycan that has a number of embryonic and wound healing properties, including the facilitation of cell migration and differentiation during tissue formation and repair [14,15]. Previous studies suggested that HA has great bacteriostatic effects on the common orthopedic and periodontal bacterial pathogens $[16,17]$. The purpose of this study is to determine the presence of any bacteriostatic or bactericidal effects of HA/CMC on selected microorganisms such as Staphylococcus aureus (S. aureus) and Escherichia 
$\operatorname{coli}($ E. coli)

\section{Materials and Methods}

\subsection{Bacterial Preparations}

The two bacterial strains, $S$. aureus (ATCC27217) and $E$. coli (ATCC25922) were purchased from the ATCC (American Type Culture Collection). S. aureus and E. coli were cultured in Dulbecco's modified Eagle's media (D-MEM) (Invitrogen Co., Tokyo, Japan) for $10 \mathrm{~h}$ at $37^{\circ} \mathrm{C}$. The culture medium was centrifuged at $1700 \times g$ for $10 \mathrm{~min}$ at room temperature to pellet the $S$. aureus or E. coli, and resuspended in sterile normal saline. A 100 $\mu \mathrm{L}$ quantity of the suspension was serially diluted with sterile saline, applied on 1.5\% Agar-B (Qbiogene, Inc.) and $0.8 \%$ Difco Nutrient Broth (Difco Laboratories, USA.) plate, and incubated for $18 \mathrm{~h}$ to determine the bacterial concentration. The remainder was stored at $-80^{\circ} \mathrm{C}$ until use. Just before use, the bacterial suspension was diluted in medium to achieve a final concentration of $5.0 \times 10^{6}$ colony-forming units $(\mathrm{cfu}) / \mathrm{mL}$. The study was approved by the local ethics committee.

\subsection{Bacterial Growth Inhibition}

Seprafilm ${ }^{\circledR}$ (HA/CMC, Genzyme Corporation, Japan) is a synthetic product of $\mathrm{HA}$ and $\mathrm{CMC}$ in the ratio of two to one. A sheet of Seprafilm ${ }^{\circledR}(12.7 \mathrm{~cm} \times 14.7 \mathrm{~cm}, 186.69$ $\mathrm{cm}^{2}$ ) weighs about $1 \mathrm{~g}$ including HA $0.7 \mathrm{~g}$ and CMC 0.3 g. A quarter sheet of $\mathrm{HA} / \mathrm{CMC}$ include approximately $175 \mathrm{mg}$ HA [18]. The incubation medium of Group A was $10 \mathrm{ml} \mathrm{D}-\mathrm{MEM}$ with a well-dissolved quarter sheet of HA/CMC (approximately $175 \mathrm{mg} \mathrm{HA}$ ). The incubation medium of Group B was $10 \mathrm{ml}$ D-MEM with a welldissolved one-eighth sheet of HA/CMC (approximately $87.5 \mathrm{mg}$ ). The incubation medium of Group $\mathrm{C}$ was only D-MEM without HA/CMC. $100 \mu \mathrm{l}$ bacterial suspension $\left(5.0 \times 10^{5}\right.$ cells $)$ was added to $100 \mu \mathrm{l}$ each group medium (total $200 \mu \mathrm{l}$ ). So, HA concentrations of medium are approximately $8.25 \mathrm{mg} / \mathrm{ml}$ in Group A, $4.125 \mathrm{mg} / \mathrm{ml}$ in Group B, and $0 \mathrm{mg} / \mathrm{ml}$ in Group C, respectively. Trials were conducted for each bacterial strain. As control, same sample size of $200 \mu \mathrm{l}$ each medium without bacteria was used in determining the optical density $\left(\mathrm{OD}_{650}\right)$ of medium. To assess the presence or absence of growth, each sample and each control were incubated using 96well cell plates (Becton Dickinson Labware, NJ, USA) at $37^{\circ} \mathrm{C}$ shaking incubater. At $0,4,8$, and 12 hours after incubation starts, the optical density $\left(\mathrm{OD}_{650}\right)$ was determined. To validate the identification of the bacteria and to rule out the possibility of contamination, 10 colonies for each bacterial strain were randomly chosen and ana- lyzed via Gram staining.

\subsection{Cellular Function Investigation}

To determine the viable count of bacteria, total adenosine triphosphate (ATP) was measured in $E$. coli and $S$. aureus after 6 hours culture. For the determination of total ATP, the BacTiter-Glo system (Promega) was used. The BacTiter-Glo buffer was mixed with the lyophilized BacTiter-Glo substrate and equilibrated at room temperature. As control, $100 \mu \mathrm{l}$ bacterial suspension $(5.0 \times$ $10^{5}$ cells) was added to $100 \mu \mathrm{l}$ medium (total $200 \mu \mathrm{l}$ ) without $\mathrm{HA} / \mathrm{CMC}$ that is similar to medium of Group $\mathrm{C}$ in bacterial growth inhibition assay (Group I). We prepared $100 \mu \mathrm{l}$ medium with well-dissolved a quarter HA/ CMC (Group II, approximately $175 \mathrm{mg} \mathrm{HA}$ ), a half of HA/CMC (Group III, approximately $350 \mathrm{mg} \mathrm{HA}$ ), one HA/CMC (Group IV, approximately $750 \mathrm{mg} \mathrm{HA}$ ), and twice HA/CMC (Group V, approximately $1500 \mathrm{mg} H \mathrm{HA}$ ). So, HA concentrations of medium are approximately 0 $\mathrm{mg} / \mathrm{ml}$ in Group I, $8.25 \mathrm{mg} / \mathrm{ml}$ in Group II, $16.5 \mathrm{mg} / \mathrm{ml}$ in Group III, $33 \mathrm{mg} / \mathrm{ml}$ in Group IV, and $66 \mathrm{mg} / \mathrm{ml}$ in Group V, respectively. Sample sizes $\left(5.0 \times 10^{5}\right.$ cells $)$ of each bacterial suspension were used in determining the initial luminescence. Each sample was incubated using 96-well cell plates (Becton Dickinson Labware, NJ, USA) for 6 hours at $37^{\circ} \mathrm{C}$ shaking incubater. Trials were conducted for each bacterial strain. At $0,2,4$, and 6 hours after incubation starts, each sample was mixed well and $100 \mu$ bacterial suspension of each well was transferred to white 96-well cell plates (Thermo Electron Corporation). An equal volume of the previously prepared BacTiter-Glo reagent was added in each well. The luminescence of the sample was measured with a multi-detection microplate reader (Powerscan HT, Dainippon Pharmaceutical, Osaka, Japan) immediately after five minutes incubation. A calibration curve with dilutions of pure rATP (Promega, P1132) was measured before each experiment. ATP value was evaluated in triplicate and the average value was computed.

\subsection{Statistics}

Statistical analyses were performed using Statview 4.5 (Abacus Concepts, Berkeley, California). Results are presented as the means $\pm \mathrm{SD}$. In bacterial growth inhibition assay, two-way repeated measures ANOVA was used to compare the each two groups with respect to bacterial growth over time. In the study of cellular function investigation assay, Spearman's rank correlation test was used to test the correlation between bacterial growth and the concentration of HA/CMC for $0,2,4$ and 6 hours. A $p$ value of $<0.05$ was considered significant. 


\section{Results}

\subsection{Bacterial Growth Inhibition}

Figure 1 shows the optical density (OD) of broth solutions with $S$. aureus during 12 hours incubation among three groups. OD curve gradually elevated and reached to plateau at 6 hours. There was a significant difference in OD between Group A and B ( $p<0.0001$ for HA/CMC concentrations and $p<0.0001$ for time $\times \mathrm{HA} / \mathrm{CMC}$ concentrations). Moreover, there was a significant difference in OD between Group A and C ( $p=0.0020$ for HA/CMC concentrations and $\mathrm{p}<0.0001$ for time $\times \mathrm{HA} / \mathrm{CMC}$ concentrations). However, there was no difference in $\mathrm{OD}$ between Group B and C. ( $p=0.0550$ for HA/CMC concentrations and $p=0.5767$ for time $\times \mathrm{HA} / \mathrm{CMC}$ concentrations). Figure 2 shows OD of broth solutions with $E$. coli during 12 hours incubation among three groups. OD curve gradually elevated and reached to plateau at 4 hours. There was a significant difference in OD between Group A and B. $(p<0.0001$ for HA/CMC concentrations and $p<0.0001$ for time $\times \mathrm{HA} / \mathrm{CMC}$ concentrations). There was a significant difference in OD between Group $\mathrm{A}$ and $\mathrm{C}(p=0.0020$ for HA/CMC concentrations and $p$ $<0.0001$ for time $\times \mathrm{HA} / \mathrm{CMC}$ concentrations). Moreover, there was a significant difference in OD between Group $\mathrm{B}$ and $\mathrm{C}(p<0.0001$ for HA/CMC concentrations and $p$ $<0.0001$ for time $\times \mathrm{HA} / \mathrm{CMC}$ concentrations).

\subsection{Cellular Function Investigation}

Figure 3 shows the serial change of mean ATP value of $S$. aureus in all groups. The mean ATP production was inhibited dose-dependently by HA/CMC and the differences in the value of ATP production are statistically significant among 5 groups at 2, 4, and 6 hours after incubation. Figure 4 shows the serial change of mean ATP value of $E$. coli in all groups. At 6 hours after incubation, the mean ATP production was inhibited dose-dependently by HA/CMC and the differences in the value of ATP production are statistically significant among 5 groups at 6 hours after incubation.

\section{Discussion}

Recently, as the usage of HA/CMC increases in abdominal surgical scene, the relationship between HA/ $\mathrm{CMC}$ and postoperative infectious complications has become the center of attention [9,11]. In the presence of infection, fibrinolysis in the abdominal cavity is even more depressed and intraabdominal adhesion becomes more severe. After contaminated or dirty operations, abscesses arising from contaminated fibrin are frequent

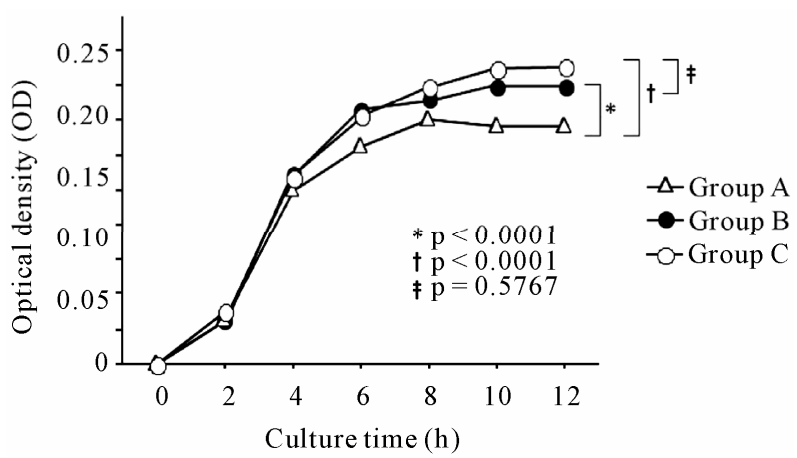

Figure 1. The optical density (OD) of broth solutions with $S$. aureus during 12 hours incubation among three groups. HA concentrations of medium are approximately $8.25 \mathrm{mg} / \mathrm{ml}$ in Group A, $4.125 \mathrm{mg} / \mathrm{ml}$ in Group B, and $0 \mathrm{mg} / \mathrm{ml}$ in Group C, respectively. There was a significant difference in $O D$ between Group A and B $\left(^{*} p<0.0001\right.$ for HA/CMC concentrations and $p<0.0001$ for time $\times$ HA/CMC concentrations). Moreover, there was a significant difference in OD between Group $A$ and $C(\dagger p=0.0020$ for HA/CMC concentrations and $p<0.0001$ for time $\times$ HA/CMC concentrations). However, there was no difference in OD between Group $B$ and $\mathrm{C}(\ddagger p=0.0550$ for HA/CMC concentrations and $p=0.5767$ for time $\times$ HA/CMC concentrations). Statistical analysis was performed by Two-Way Repeated-Measures ANOVA.

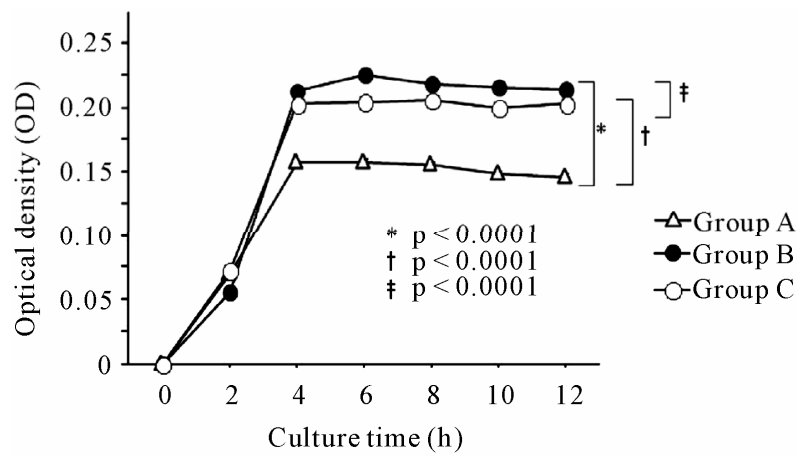

Figure 2. The optical density (OD) of broth solutions with $E$. coli during 12 hours incubation among three groupos. HA concentrations of medium are approximately $8.25 \mathrm{mg} / \mathrm{ml}$ in Group A, $4.125 \mathrm{mg} / \mathrm{ml}$ in Group B, and $0 \mathrm{mg} / \mathrm{ml}$ in Group C, respectively. OD curve gradually elevated and reached to plateau at 4 hours. There was a significant difference in OD between Group A and B (*p $<0.0001$ for HA/CMC concentrations and $p<0.0001$ for time $\times$ HA/CMC concentrations). There was a significant difference in OD between Group A and $C(\dagger p=0.0020$ for HA/CMC concentrations and $p<$ 0.0001 for time $\times$ HA/CMC concentrations). Moreover, there was a significant difference in OD between Group B and $C(\ddagger p<0.0001$ for HA/CMC concentrations and $p<$ 0.0001 for time $\times$ HA/CMC concentrations). Statistical analysis was performed by Two-Way Repeated-Measures ANOVA.

complications. In the treatment of infection development in the abdominal cavity, elimination of the source of contamination is the cornerstone of abdominal surgery. 


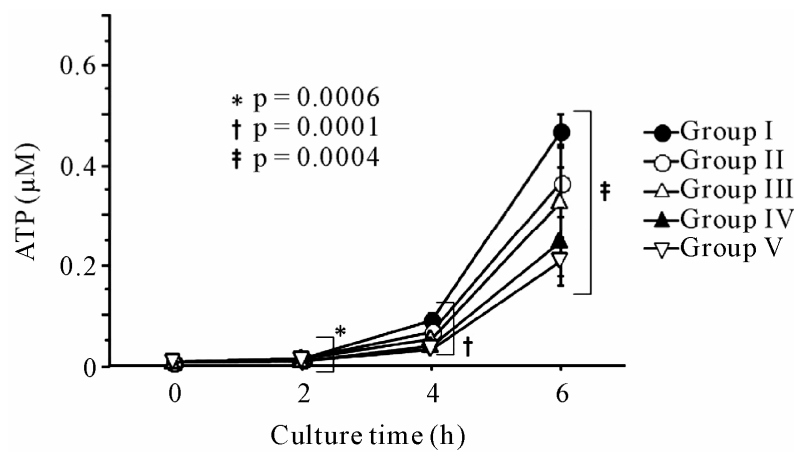

Figure 3. The serial change of mean ATP value of $S$. aureus in all groups. HA concentrations of medium are approximately $0 \mathrm{mg} / \mathrm{ml}$ in Group I, $8.25 \mathrm{mg} / \mathrm{ml}$ in Group II, 16.5 $\mathrm{mg} / \mathrm{ml}$ in Group III, $33 \mathrm{mg} / \mathrm{ml}$ in Group IV, and $66 \mathrm{mg} / \mathrm{ml}$ in Group V, respectively. The mean ATP production was inhibited dose-dependently by HA/CMC and the differences in the value of ATP production are statistically significant among 5 groups at 2, 4, and 6 hours after incubation. ${ }^{*} p=0.0006, \dagger p=0.0001, \neq p=0.0004$ (Spearman’s rank correlation test).

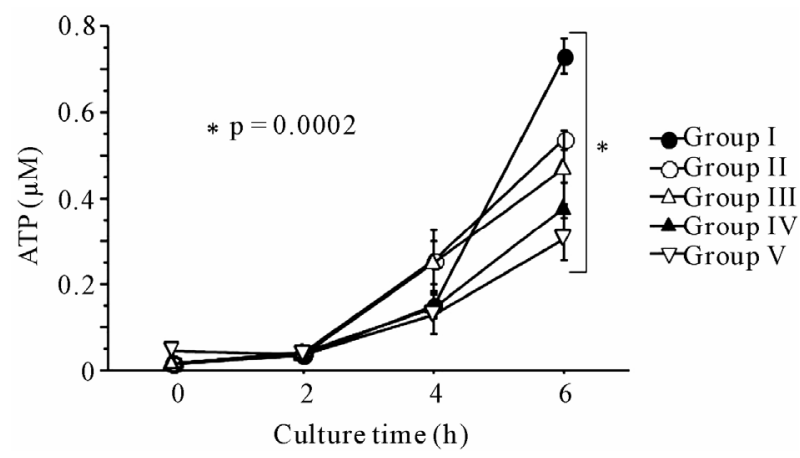

Figure 4. The serial change of mean ATP value of $E$. coli in all groups. HA concentrations of medium are approximately $0 \mathrm{mg} / \mathrm{ml}$ in Group I, $8.25 \mathrm{mg} / \mathrm{ml}$ in Group II, 16.5 $\mathrm{mg} / \mathrm{ml}$ in Group III, $33 \mathrm{mg} / \mathrm{ml}$ in Group IV, and $66 \mathrm{mg} / \mathrm{ml}$ in Group V, respectively. At 6 hours after incubation, the mean ATP production was inhibited dose-dependently by $\mathrm{HA} / \mathrm{CMC}$ and the differences in the value of ATP production are statistically significant among 5 groups at 6 hours after incubation. $* p=0.0002$ (Spearman's rank correlation test).

Fibrin forms deposits that are a matrix for ingrowth of fibrocollagenous tissue. Moreover, fibrin clots protect bacteria against the immunological defences of the abdominal cavity. Following this pathway, intraabdominal fibrin may eventually lead to adhesion and/or abscess formation. Persistence and reinforcement of fibrinolysis is needed after surgery new fibrin deposits will occur.

Animal experiments have demonstrated that enhancement of fibrinolysis reduces intraabdominal abscess formation $[19,20]$. Several mechanisms may be involved in the reduction of adhesions by HA/CMC, including mechanical separation of wound surfaces, improvement of peritoneal healing and enhanced fibrinolysis. Reijnen et al. [9] reviewed investigations into the pathophysiology of intra-abdominal adhesions and abscess formation, and showed that the potential of hyaluronan-based agents to reduce intra-abdominal adhesions and abscess on abdominal surgery and sepsis is a promising new concept. Previous study at our institute demonstrated that HA/ $\mathrm{CMC}$ itself does not affect the functions of isolated human Polymorphonuclear neutrophils in in vitro experimental models of inflammation and endotoxin-stimulation [12]. In this study, we tried to determine whether hyaluronan-based bioresorbable membrane HA/CMC reduces the bacterial growth. In growth inhibition assay, we investigated the effect of HA/CMC on both the logarithmic growth phase and stationary phase. And we put emphasis on the effect of HA/CMC itself on the total number of bacteria. In this assay, the logarithmic growth phase of $S$. aureus and E. coli continued for 6 hours at least. In cellular function investigation, we put emphasis on the association between the viablility of bacteria and the concentration of HA/CMC. Therefore, we investigated the effect of HA/CMC to the logarithmic growth phase for 6 hours by measuring total ATP.

HA modulates the inflammatory response; it has free radical scavenging and antioxidant properties [21], and increases interferon $\gamma$ levels during peritonitis, inhibits inflammatory proteinases [22], and probably induces the production of proinflammatory mediators such as interleukin 1, interleukin 8 and TNF- $\alpha$ [23]. The role of HA in the resistance of bacteria to opsonization and phgocytic killing is not completely understood [24]. Carlson et al. [5] suggested that the bacteriostatic effect of HA may be due to the saturation of the bacterial hyaluronate lyase by the excess HA, which prevents the bacteria from maintaining elevated levels of tissue permeability and penetrating the physical defenses of the host. This would enhance the ability of the host's immune system to eradicate pathogens. HA molecules also form a random network of chains that may act as a sieve preventing the spread of the bacteria.

Pirnazar et al. [17] demonstrated the bacteriostatic effects of HA on selected oral and non-oral microorganisms. They suggested that HA has no bactericidal effect, however, the high concentrations $(2.0 \mathrm{mg} / \mathrm{ml})$ of the medium $(757 \mathrm{kD})$ molecular weight (MW) HA had the greatest bacteriostatic effect on several bacterial strains compared to the combinations with other concentrations $(0.5$ or $1.0 \mathrm{mg} / \mathrm{ml})$ and $\mathrm{MW}(141 \mathrm{kD}$ or $1300 \mathrm{kD})$. HA in $\mathrm{HA} / \mathrm{CMC}$ and has been esterified with glucuronic acid residues and is different from native HA in the human body. Based on light-scattering measurements, the modified HA in comprises molecules of approximately 100 $\mathrm{kD}$ in MW [18]. HA/CMC is a synthetic product of HA 
and $\mathrm{CMC}$ in the ratio of two to one. A sheet of $\mathrm{HA} / \mathrm{CMC}$ $\left(12.7 \mathrm{~cm} \times 14.7 \mathrm{~cm}, 186.69 \mathrm{~cm}^{2}\right)$ weighs about $1 \mathrm{~g}$ including HA $0.7 \mathrm{~g}$ and CMC $0.3 \mathrm{~g}$. A quarter sheet of HA/ CMC include approximately $175 \mathrm{mg}$ HA. The concentration of HA formulation used in Group A was $3.5 \mathrm{mg} / \mathrm{ml}$ and higher compared to Pirnazar's study. This study clarified the higher concentrations of HA/CMC introduced, the greater bacteriostatic effects on S. aureus and E. coli using bacterial growth inhibition and cellular function investigation. In conclusion, $\mathrm{HA} / \mathrm{CMC}$ may have dose-dependently bacteriostatic effects on $S$. aureus and E. coli. Further investigations are needed about various bacterial strains which could be present in the abdominal cavity.

\section{References}

[1] J. M. Becker, M. T. Dayton, V. W. Fazio, D. E. Beck, S. J. Stryker, S. D. Wexner, et al., "Prevention of Postoperative Abdominal Adhesions by a Sodium Hyaluronate-Based Bioresorbable Membrane: A Prospective, Randomized, Double-Blind Multicenter Study," Journal of the American College of Surgeons, Vol. 183, No. 4, 1996, pp. 297-306.

[2] Y. Mohri, K. Uchida, T. Araki, Y. Inoue, H. Tonouchi, C. Miki, et al., "Hyaluronic Acid-Carboxycellulose Membrane (Seprafilm $\left.{ }^{\circledR}\right)$ Reduces Early Postoperative Small Bowel Obstruction in Gastrointestinal Surgery," The American Surgeon, Vol. 71, No. 10, 2005, pp. 861-863.

[3] M. Kusunoki, H. Ikeuchi, H. Yanagi, M. Noda, H. Tonouchi, Y. Mohri, et al., "Bioresorbable Hyaluronate-Carboxymethylcellulose Membrane (Seprafilm) in Surgery for Rectal Carcinoma: A Prospective Randomized Clinical Trial," Surgery Today, Vol. 35, No. 11, 2005, pp. 940-945. doi:10.1007/s00595-005-3061-0

[4] M. Inoue, K. Uchida, C. Miki and M. Kusunoki, "Efficacy of Seprafilm for Reducing Reoperative Risk in Pediatric Surgical Patients Undergoing Abdominal Surgery," Journal of Pediatric Surgery, Vol. 40, No. 8, 2005, pp. 1301-1306. doi:10.1016/j.jpedsurg.2005.05.015

[5] P. J. Klingler, N. R. Floch, M. H. Seelig, S. A. Branton, J. T. Wolfe and P. P. Metzger, "Seprafilm-Induced Peritoneal Inflammation: A Previously Unknown Complication-Report of a Case," Diseases of the Colon \& Rectum, Vol. 42, No. 12, 1999, pp. 1639-1643. doi:10.1007/BF02236221

[6] F. H. Remzi, M. Oncel, J. M. Church, A. J. Senagore, C. P. Delaney and V. W. Fazio, "An Unusual Complication after Hyaluronate-Based Bioresorbable Membrane (Seprafilm) Application," The American Surgeon, Vol. 69, No. 4, 2003, pp. 356-357.

[7] A. O. Tzianabos, R. L. Cisneros, J. Gershkovich, J. Johnson, R. J. Miller, J. W. Burns, et al., "Effect of Surgical Adhesion Reduction Devices on the Propagation of Experimental Intra-Abdominal Infection," Archives of Surgery, Vol. 134, No. 11, 1999, pp. 1254-1259. doi:10.1001/archsurg.134.11.1254

[8] A. Tuzune, M. A. Kuzu, B. Akin, S. Karaca and S. Hazi- nedaroglu, "The Effect of Hyaluronan-Based Agents on Adhesion Formation in an Intra-Abdominal Sepsis Model," Digestive Diseases and Sciences, Vol. 49, No. 6, 2004, pp. 1054-1061. doi:10.1023/B:DDAS.0000034571.30602.36

[9] M. M. Reijnen, J. F. Meis, V. A. Postma and H. van Goor, "Prevention of Intra-Abdominal Abscesses and adhesions Using a Hyaluronic Acid Solution in a Rat Peritonitis Model," Archives of Surgery, Vol. 134, No. 9, 1999, pp. 997-1001. doi:10.1001/archsurg.134.9.997

[10] A. M. Ghellai, A. F. Stucchi, D. J. Lynch, K. C. Skinner, M. J. Colt and J. M. Becker, "Role of a HyaluronateBased Membrane in the Prevention of Peritonitis-Induced Adhesions," Journal of Gastrointestinal Surgery, Vol. 4, No. 3, 2000, pp. 310-315. doi:10.1016/S1091-255X(00)80081-5

[11] K. Uchida, H. Urata, Y. Mohri, M. Inoue, C. Miki and M. Kusunoki, "Seprafilm ${ }^{\circledR}$ Does Not Aggravate Intraperitoneal Septic Conditions or Evoke Systemic Inflammatory Response," Surgery Today, Vol. 35, No. 12, 2005, pp. 1054-1059. doi:10.1007/s00595-005-3085-5

[12] K. Otake, K. Uchida, S. Yoshiyama, M. Inoue, Y. Okita, H. Watanabe, et al., "Effects of a Hyaluronate-CarboxyMethylcellulose Membrane (Seprafilm) on Human Polymorphonuclear Neutrophil Functions," Journal of Surgical Research, Vol. 149, No. 2, 2008, pp. 243-249. doi:10.1016/i.jss.2008.01.011

[13] J. W. Burns, M. J. Colt, L. S. Burgees and K. C. Skinner, "Preclinical Evaluation of Seprafilm Bioresorbable Membrane," European Journal of Surgery, No. 577, 1997, pp. 40-48.

[14] B. P. Toole, In: D. E. Hay, Ed., Cell Biology of Extracellular Matrix, Plenum Press, New York, 1991, pp. 305-341.

[15] C. N. Bertolami, "Glycosaminoglycan Interactions in Early Wound Repair," In: T. K. Hunt, R. B. Heppenstall, E. Pines, et al., Eds., Soft and Hard Tissue Repair, Biological and Clinical Aspects, Praeger Publishers, New York, 1984, pp. 67-97.

[16] G. A. Carlson, J. L. Dragoo, B. Samimi, D. A. Bruckner, G. W. Bernard, M. Hedrick, et al., "Bacteriostatic Properties of Biomatrices against Common Orthopaedic Pathogens," Biochemical and Biophysical Research Communications, Vol. 321, No. 2, 2004, pp. 472-478. doi:10.1016/j.bbrc.2004.06.165

[17] P. Pirnazar, L. Wolinsky, S. Nachnani, S. Haake, A. Pilloni and G. W. Bernard, "Bacteriostatic Effects of Hyaluronic Acid," Journal of Periodontology, Vol. 70, No. 4, 1999, pp. 370-374. doi:10.1902/jop.1999.70.4.370

[18] S. C. Hubbard and J. W. Burns, "Effects of a HyaluronanBased Membrane (Seprafilm) on Intraperitoneally Disseminated Human Colon Cancer Cell Growth in a Nude Mouse Model," Diseases of the Colon \& Rectum, Vol. 45, No. 3, 2002, pp. 334-344. doi:10.1007/s10350-004-6178-0

[19] H. van Goor, J. S. de Graaf, K. Kooi, W. J. Sluiter, V. J. Bom, J. van der Meer, et al., "Effect of Recombinant Tissue Plasminogen Activator on Intra-Abdominal Abscess Formation in Rats with Generalized Peritonitis," Journal of the American College of Surgeons, Vol. 179, No. 4, 
1994, pp. 407-411.

[20] D. I. McRitchie, D. Cummings and O. D. Rotstein, "Delayed Administration of Tissue Plasminogen Activator Reduces Intra-Abdominal Abscess Formation," Archives of Surgery, Vol. 124, No. 12, 1989, pp. 1406-1410.

[21] D. Foschi, L. Castoldi, E. Radaelli, P. Abelli, G. Calderini, A. Rastrelli, et al., "Hyaluronic Acid Pevents Oxygen Free-Radical Damage to Granulation Tissue: A Study in Rats," International Journal of Tissue Reactions, Vol. 12, No. 6, 1990, pp. 333-339.

[22] M. Akatsuka, Y. Yamamoto, K. Tobetto, T. Yasui and T. Ando, "Suppressive Effects of Hyaluronic Acid on Elastase Release from Rat Peritoneal Leucocytes," Journal of
Pharmacy and Pharmacology, Vol. 45, No. 2, 1993, pp. 110-114. doi:10.1111/j.2042-7158.1993.tb03693.x

[23] D. Hiro, A. Ito, K. Matsuta and Y. Mori, "Hyaluronic Acid Is an Endogenous Inducer of Interleukin-1 Production by Human Monocytes and Rabbit Macrophages," Biochemical and Biophysical Research Communications, Vol. 140, No. 2, 1986, pp. 715-722.

[24] A. E. Moses, M. R. Wessels, K. Zalcman, S. Alberti, S. Natanson-Yaron, T. Menes, et al., "Relative Contributions of Hyaluronic Acid Capsule and M Protein to Virulence in a Mucoid Strain of the Group A Streptococcus,' Infection and Immunity, Vol. 65, No. 1, 1997, pp. 64-71. 